\title{
Questionnaire survey of customer satisfaction for product categories towards certification of ergonomic quality in design
}

\author{
Masaaki Mochimaru ${ }^{\mathrm{a},{ }^{*}}$, Miwako Takahashi ${ }^{\mathrm{b}}$, Nobuko Hatakenaka ${ }^{\mathrm{b}}$ and Hitoshi Horiuchi ${ }^{\mathrm{b}}$ \\ ${ }^{a}$ Digital Human Research Center, 2-3-26 Aomi, Koto-ku, Tokyo, Japan \\ ${ }^{\mathrm{b}}$ Research Institute of Human Engineering for Quality Life, Osaka, Japan \\ ${ }^{\mathrm{c}}$ Delphis Inc., Tokyo, Japan
}

\begin{abstract}
Customer satisfaction was surveyed for 6 product categories (consumer electronics, daily commodities, home equipment, information systems, cars, and health appliances) by questionnaires based on the Analytic Hierarchy Process. Analyzing weight of evaluation factors, the 6 product categories were reorganized into 4 categories, those were related to 4 aspects in daily living that formed by two axes: home living - mobility life and healthy life - active communication. It was found that consumers were attracted by the actual user test by public institutes for all product categories. The certification based on the design process standard established by authorities, such as EQUID was the second best attractor for consumers.
\end{abstract}

Keywords: customer satisfaction, analytic hierarchy process, ergonomic quality in design

\section{Introduction}

Certification of ergonomic quality in design is under discussion in the IEA standing committee (EQUID) and ISO TC159/SC1. It is understood that the certification will be an attractor to consumers, and products with the certification will distribute in the market. Customers may have different evaluation factors for different product categories. The certification should be designed with understanding evaluation factors for product categories. The purpose of the present survey is to clarify the customer satisfaction for product categories in order to establish the certification of ergonomic quality in design.

\section{Method}

Questionnaire survey was designed to clarify differences of customer satisfaction in product categories. The framework of the questionnaire was formed as paired comparison method based on the Analytic Hierarchy Process. Evaluation factors of question- naire were selected from "Human Design Technology" proposed by Yamaoka [1]. Products were categorized into 6 segments, such as consumer electronics, daily commodities, home equipment, information systems, cars, and health appliances. The questionnaire was formed into hierarchical structure with 5 levels (figure 1). The first level is the purpose of this study, and the second level is the product category. The third level had 5 basic evaluation factors, such as safety, validity, usability, style design, and augmentability. The fourth level is detailed evaluation factors. As the sixth level, we add incentive rate of the certification for comsumers.

Participants were selected as consumers that request high quality in design. An investigator visited every participant and explained the purpose of the survey before starting the questionnaire. 133 valid samples were obtained. Weight for every evaluation factor was calculated, and the priority of factors was clarified. Differences of customer satisfaction were discussed based on evaluation factors with high priority.

\footnotetext{
*Corresponding author. E-mail: m-mochimaru@aist.go.jp.
} 


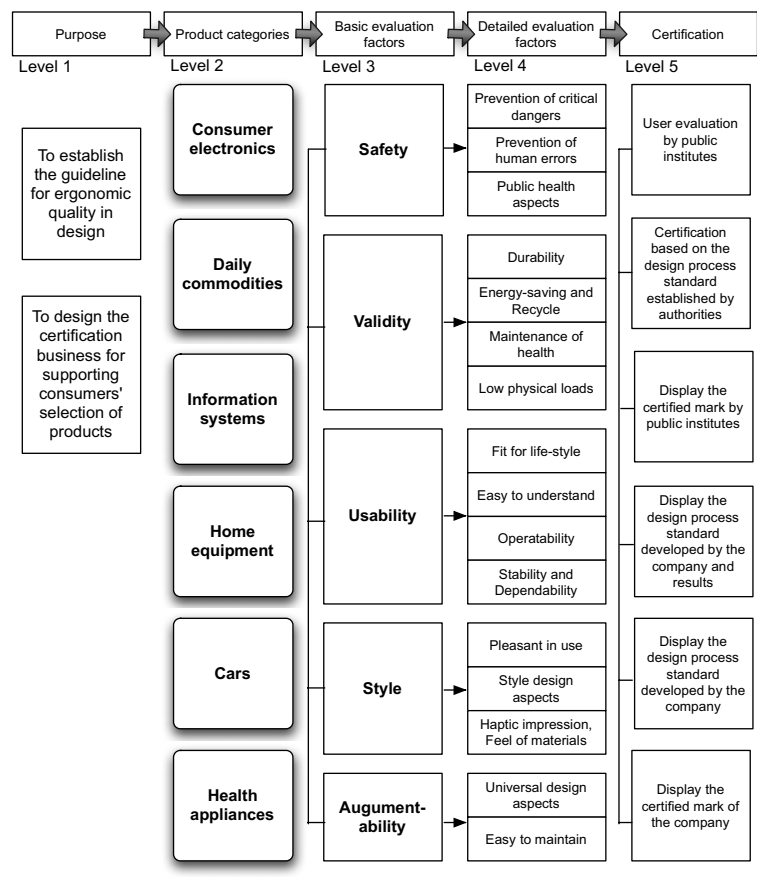

Figure 1 Questionnaire design based on AHP

\section{Results}

\subsection{Analysis for basic factors}

Results are shown in figure 2. Factors in the black cell indicate high priority factors of the basic level, and factors in the gray cell indicate high priority factors of the derailed level. The order of factors was different in product categories. Usability was the most important factor for the product categories of consumer electronics, daily commodities and information systems. Whereas, safety was the most important factors for the product categories of home equipment, cars and health appliances. Small differences were founded in the weight of the first to the third priority of consumer electronics, home equipment and health appliances. Thus, the order of the top three factors was not so important for these product categories. The top three factors were safety, validity and usability.

Especially for the product category of home equipment, small differences were founded in the weight of top four priorities. Consumer satisfaction was not so intensive. The weight of safety is significantly smaller for information systems, and significantly higher for cars.

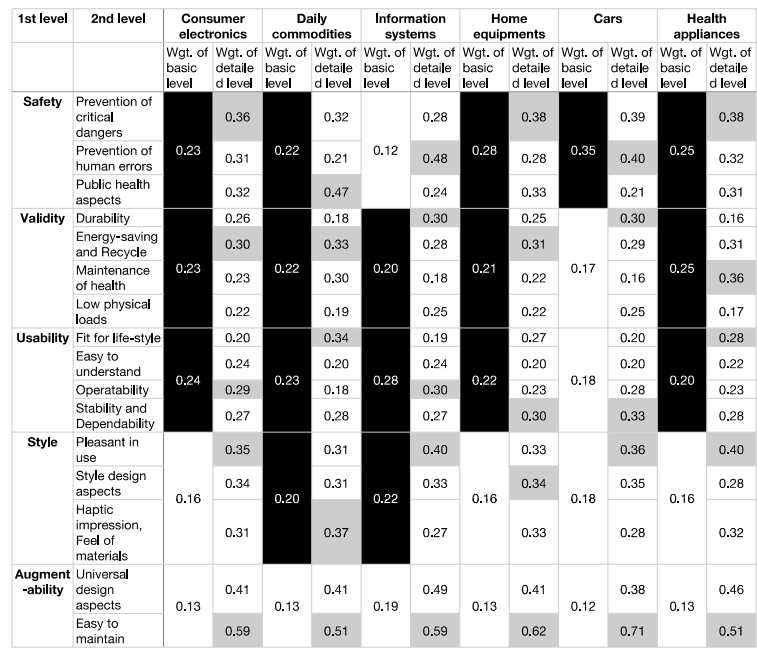

Figure 2 Weight of evaluation factors

\subsection{Analysis for detailed factors}

Usability was the top priority in basic level factors for the product categories of consumer electronics, daily commodities and information systems. For consumer electronics and information systems, operatability is the top priority for the detailed level in the usability factors. For home equipments, whereas, the factor of fit for life-style was the top priority for the derailed level in the usability factors. Focusing on the factor of safety as the basic level, the detailed level factor of prevention of critical dangers was the top priority for consumer electronics, home equipment and health appliances. For information systems and cars, prevention of human errors was the top priority in the detailed level factors. For daily commodities, public health aspects were most important factors in the safety.

\subsection{Incentive rates of the certification}

Through this survey, we asked the incentive rate of the certification. The highest incentive rate of certification for all product categories was actual user test by public institutes. The second highest rate was the certification based on the design process standard established by authorities. 


\section{Discussion}

\subsection{Reorganization of product categories}

Those factors can be divided into two groups (figure 3 ). One is the ordinary quality and the other is the attractive quality. The ordinary quality is necessary induce consumer to buy. The ordinary quality such as safety was required for home equipment and cars. The common ordinary qualities were required for consumer electronics, daily commodities and home equipments. Whereas, the ordinary quality of validity and the attractive quality of pleasant in use were required for health appliance. For information systems, the attractive qualities were highly required.

As results, it was found that evaluation factors for consumer electronics, daily commodities and home equipment were common.

Therefore, 6 product categories can be reconstruct into 4 categories (home appliances, health appliances, cars, and information systems). Those 4 product categories have independent evaluation factors of customer satisfaction, and those are connected to 4 aspects in daily living. Information systems are related to communication, home appliances are related to home living, health appliances are related to healthy life and cars are related to mobility life (figure 4). Those 4 categories are also related to human functioning in daily activities. Human functioning is standardized as ICF (International Classification of Functioning, Disability and Health) by WHO [2].

It was found that customer satisfaction was different in 4 product categories. Therefore, certification of ergonomic quality should concern those differences of customer satisfaction. If certification of ergonomic quality focuses on only the ordinary quality, it can be valid only in the product categories of mobility life (cars) and a part of daily living (home equipment).

\begin{tabular}{|c|c|c|c|}
\hline Basic level & Detailed level & Ordinal quality & Attractive quality \\
\hline \multirow[t]{7}{*}{ Safety } & \multirow{4}{*}{$\begin{array}{l}\text { Prevention of } \\
\text { critical dangers }\end{array}$} & Difficult to see & Inter-locking \\
\hline & & Difficult to hear & \multirow{3}{*}{$\begin{array}{l}\text { Well controlled } \\
\text { considering human } \\
\text { errors }\end{array}$} \\
\hline & & Difficult to grasp & \\
\hline & & Difficult to hold & \\
\hline & $\begin{array}{l}\text { Prevention of } \\
\text { human errors }\end{array}$ & Likely to be injured & \\
\hline & \multirow[t]{2}{*}{$\begin{array}{l}\text { Public health } \\
\text { aspects }\end{array}$} & $\begin{array}{l}\text { Likely to ruin } \\
\text { health }\end{array}$ & \\
\hline & & Dirty & \\
\hline \multirow[t]{9}{*}{ Validity } & \multirow[t]{2}{*}{ Durability } & & $\begin{array}{l}\text { To be used for long- } \\
\text { term }\end{array}$ \\
\hline & & & Difficult to be broken \\
\hline & \multirow{2}{*}{$\begin{array}{l}\text { Energy-saving } \\
\text { and Recycle }\end{array}$} & & Recyclable \\
\hline & & & $\begin{array}{l}\text { Made of ecological } \\
\text { materials }\end{array}$ \\
\hline & \multirow{2}{*}{$\begin{array}{l}\text { Maintenance of } \\
\text { health }\end{array}$} & & To prevent disease \\
\hline & & & $\begin{array}{l}\text { To enhance health } \\
\text { condition }\end{array}$ \\
\hline & \multirow[t]{3}{*}{$\begin{array}{l}\text { Low physical } \\
\text { loads }\end{array}$} & $\begin{array}{l}\text { Likely to be } \\
\text { fatigued }\end{array}$ & Easy to use \\
\hline & & Difficult to do & Fit to the human body \\
\hline & & & Low physical loads \\
\hline \multirow[t]{14}{*}{ Usability } & \multirow[t]{2}{*}{ Fit for life-style } & & $\begin{array}{l}\text { Fit to the individual } \\
\text { preference }\end{array}$ \\
\hline & & & $\begin{array}{l}\text { To enhance users' } \\
\text { skill }\end{array}$ \\
\hline & \multirow{4}{*}{$\begin{array}{l}\text { Easy to } \\
\text { understand }\end{array}$} & Difficult to use & Easy to distinguish \\
\hline & & Inadequate display & $\begin{array}{l}\text { Low psychological } \\
\text { loads }\end{array}$ \\
\hline & & Difficult to touch & $\begin{array}{l}\text { Fit to the individual } \\
\text { mental model }\end{array}$ \\
\hline & & Difficult to learn & Consistency \\
\hline & \multirow[t]{6}{*}{ Operatability } & $\begin{array}{l}\text { Not fit to the } \\
\text { human body }\end{array}$ & \multirow[t]{6}{*}{ Intuitive operation } \\
\hline & & $\begin{array}{l}\text { Too small or too } \\
\text { large }\end{array}$ & \\
\hline & & $\begin{array}{l}\text { Too quick or too } \\
\text { slow }\end{array}$ & \\
\hline & & $\begin{array}{l}\text { Too heavy or too } \\
\text { light }\end{array}$ & \\
\hline & & $\begin{array}{l}\text { Too bright or too } \\
\text { dark }\end{array}$ & \\
\hline & & $\begin{array}{l}\text { Too high or too } \\
\text { low }\end{array}$ & \\
\hline & \multirow{2}{*}{$\begin{array}{l}\text { Stability and } \\
\text { Dependability }\end{array}$} & & Error prevention \\
\hline & & & Security \\
\hline \multirow[t]{6}{*}{ Style } & \multirow[t]{2}{*}{ Pleasant in use } & & $\begin{array}{l}\text { To enhance } \\
\text { experiences }\end{array}$ \\
\hline & & & Not to get tired \\
\hline & \multirow{2}{*}{$\begin{array}{l}\text { Style design } \\
\text { aspects }\end{array}$} & & Good combination \\
\hline & & & To raise morale \\
\hline & \multirow{2}{*}{$\begin{array}{l}\text { Haptic } \\
\text { impression, Feel } \\
\text { of materials }\end{array}$} & & Soft to touch \\
\hline & & & Good feel of materials \\
\hline \multirow[t]{5}{*}{$\begin{array}{l}\text { Augment- } \\
\text { ability }\end{array}$} & $\begin{array}{l}\text { Universal design } \\
\text { aspects }\end{array}$ & & $\begin{array}{l}\text { Accessible for every } \\
\text { person }\end{array}$ \\
\hline & \multirow[t]{4}{*}{ Easy to maintain } & Difficult to repair & Easy to repair \\
\hline & & Difficult to keep & Easy to move \\
\hline & & Difficult to handle & Easy to share \\
\hline & & Difficult to dispose & \\
\hline
\end{tabular}

Figure 3 Ordinal quality and attractive quality 


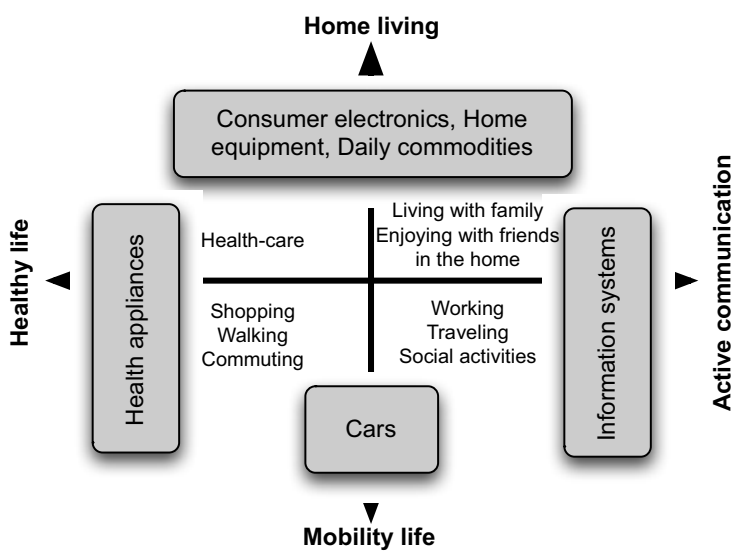

Figure 4 Reorganization of product categories based on the human functioning aspect

\subsection{Importance of certification}

The certification of ergonomic quality can be an attractor to consumers, whereas it should be established by IEA or ISO, not a private company. Moreover, the certification should cover not only the ordinary quality but also the attractive quality.

\section{Conclusions}

Customer satisfaction was surveyed for 6 product categories by questionnaires based on the Analytic Hierarchy Process. Analyzing weight of evaluation factors, the 6 product categories were reorganized into 4 categories, those were related to 4 aspects in daily living that formed by two axes: home living mobility life and healthy life - active communication. It was found that consumers were attracted by the actual user test by public institutes for all product categories. The certification based on the design process standard established by authorities, such as EQUID was the second best attractor for consumers.

\section{References}

[1] Yamaoka, T. (2001) Human Design Technology as a New Product Design Method, First International Conference on Planning and Design, Taipei, CD JP003-F, pp.1.

[2] WHO (2001) International Classification of Functioning, Disability and Health (ICF), http://www.who.int/classifications/icf/en/. 